Jurnal Kesehatan

Volume 12, Nomor 3, Tahun 2021

ISSN 2086-7751 (Print), ISSN 2548-5695 (Online) http://ejurnal.poltekkes-tjk.ac.id/index.php/JK

\title{
Bermain Buku Pop-Up sebagai Terapi Gangguan Mental Emosional Pasca Bencana Tsunami
}

\section{Playing Pop-Up Books as a Therapy for Mental Emotional Problems after the Tsunami Disaster}

\author{
Sulastri $^{1}$, Rohayati ${ }^{2}$, Sary Febriaty ${ }^{3}$ \\ Jurusan Keperawatan, Politeknik Kesehatan Tanjung Karang, Indonesia
}

\section{ARTICLE INFO}

\section{Article history}

Received date

01 Oct 2021

Revised date

14 Oct 2021

23 Nov 2021

Accepted date

24 Nov 2021

\section{Keywords:}

Children's emotional mentality;

Play therapy;

Pop-up books;

Tsunami.

\section{Kata kunci:}

Mental emosional anak; Terapi bermain; Pop-up books; Tsunami.

\author{
ABSTRACT/ ABSTRAK
}

Traumatic experiences can trigger mental-emotional problems in children, especially in disaster conditions. The purpose of this study is to describe mental and emotional problems in children in South Lampung after the Sunda Strait tsunami natural disaster after being given playing therapy with pop-up books. This study uses a quantitative design with quasi-experimental treatment. The population in this study were preschool and school-age children affected by the Sunda Strait tsunami who lived in temporary village shelters in three villages namely Way Muli Timur, Way Muli Barat, and Kunjir as many as 93 children. The mental-emotional state of the child will be measured before and after therapy. Data collection using the Strength Difficulties Questionnaire questionnaire. The test was conducted using the dependent t-test. The results of data analysis showed that in general the level of strength and difficulty of children was abnormally susceptible $(63,4 \%)$ at the beginning of the measurement and increased towards normal, in other words, there was an effect of playing therapy with pop-up books on the child's emotional mentality. The results of the bivariate test showed that there was an effect of pop-up books play therapy on children's mental-emotional problems ( $p$-value 0,002). It is recommended that play therapy be combined with other therapies, including consistently to reinforce for children from those closest to them, such as nuclear family and other children's closest people.
Pengalaman traumatis bisa menjadi pemicu masalah mental emosional pada anak, khususya pada kondisi bencana Tujuan penelitian ini mendeskripsikan masalah mental dan emosional pada anak di Lampung Selatan Pasca bencana alam tsunami selat Sunda setelah diberi terapi bermain dengan pop-up books. Penelitian ini menggunakan desain kuantitatif dengan pemberian perlakukan/eksperimen semu. Populasi dalam penelitian ini adalah anak-anak prasekolah dan usia sekolah yang terdampak tsunami selat sunda yang tinggal di hunian sementara desa di tiga desa yaitu Way Muli Timur, Way Muli Barat, dan Kunjir sebanyak 93 anak. Kondisi mental emosi anak akan diukur sebelum dan setelah terapi. Pengambilan data menggunakan kuesioner Strength Difficulties Questionnaire. Uji dilakukan mengunakan uji t-dependent. Hasil analisis data diperoleh secara umum tingkat kekuatan dan kesulitan anak pada rentan abnormal $(63,4 \%)$ pada awal pengukuran dan mengalami peningkatan kearah normal, dengan kata lain ada pengaruh terapi bermain dengan pop-up books dengan mental emosional anak. Hasil uji bivariat menunjukkan ada pengaruh terapi bermain pop-up books terhadap masalah mental emosional anak ( $p$-value 0,002). Disarankan terapi bermain dengan dikombinasi dengan terapi lain termasuk secara konsisten untuk memberikan penguatan pada anak dari orang terdekat, seperti keluarga inti dan orang terdekat anak lainnya.

Corresponding Author:

Sulastri

Jurusan Keperawatan, Politeknik Kesehatan Tanjung Karang, Indonesia

Email: sulastri@poltekkes-tjk.ac.id 


\section{PENDAHULUAN}

Peristiwa bencana alam Tsunami yang terjadi di selat sunda masih menyisakan duka yang mendalam, khususnya anak-anak di wilayah terdampak paling parah yaitu desa Kunjir, Way Muli, dan Way Muli Timur. Banyak penduduk yang merasakan dampaknya, termasuk anakanak. Masa kanak-kanak merupakan kelompok yang rentan dan kritis dalam siklus perkembangan seseorang, dimana pada masa ini terjadi banyak perubahan, baik perubahan biologis, psikologis maupun perubahan sosial. Fase perubahan tersebut seringkali memicu terjadinya konflik antara anak dengan dirinya sendiri maupun konflik dengan lingkungan sekitarnya. Apabila konflik-konflik tersebut tidak dapat teratasi dengan baik maka dalam perkembangannya dapat membawa dampak negatif terutama terhadap pematangan karakter anak dan tidak jarang memicu terjadinya gangguan mental.

Kelainan mental, emosional dan perilaku (mental emosional behaviour disorders) seperti depresi, masalah perilaku dan penyalahgunaan zat di antara anak-anak meyebabkan beban yang berat bagi keluarga, bangsa dan diri mereka sendiri. Selain kesehatan fisik, kesehatan mental merupakan faktor yang penting bagi masa depan dan kesejahteraan anak dimasa yang akan datang. Empat belas sampai dua puluh persen remaja mengalami kelainan mental, emosional dan perilaku. Survey menunjukkan bahwa 50\% dari seluruh kasus yang didiagnosa kelainan mental dimulai sejak usia 14 tahun (Radityo, et al., 2012).

Setelah bencana terjadi, anak harus pindah dari situasi dan rutinitas keseharian yang membuatnya aman dan nyaman. Ada yang kehilangan orang tua atau saudara, ada yang pindah dari rumah dan tinggal sementara waktu di tempat pengungsian, bahkan ada yang tidak bisa bersekolah, bermain dan mendapatkan istirahat yang cukup. Oleh karena itu, diperlukan metode dan media yang tepat untuk membantu anak mengekspresikan rasa takut, cemas, pesimis dan menumbuhkan harapan serta optimisme mengenai masa yang akan datang.

Setiap kejadian bencana alam, rata-rata penduduk yang mengalami masalah kejiwaan mencapai 50\%. Oleh sebab itu, selain membutuhkan pasokan logistik, para korban bencana alam juga memerlukan terapi pemulihan stres dan trauma. Salah satunya dengan terapi bermain (Rahmadian, et al., 2016). Pada penelitian ini peneliti menggunakan terapi bermain sebagai perlakuan. Terapi yang digunakan adalah pop-up books. Pop-up books mampu menurunkan kecemasan pada anak (Handayani, et al., 2017).

Bencana alam Tsunami selat sunda yang terjadi pada Desember 2018 lalu meninggalkan dampak psikologis termasuk pada anak-anak. Saat ini warga yang kehilangan tempat tinggal, disiapkan hunian sementara. Ada tiga hunian sementara terbanyak yaitu Way Muli Timur sebanyak 443 jiwa, Way Muli Barat 157 jiwa dan Kunjir 378 jiwa. Dari 978 jiwa, 176 diataranya adalah anak-anak. Hasil pre-survey yang dilakukan pada 10 anak di tiga pengungsian diperoleh informasi sebagian besar anak-anak menunjukkan respons masalah emosional, seperti sering mengeluh tidak nyaman pada perut dan sakit kepala pasca bencana, tampak khawatir saat mendengar suara keras dan hujan deras, mudah menangis dan sedih, takut saat ditinggal orang tua dan mudah khawatir. Kondisi ini jelas membutuhkan intervensi yang sesuai dengan tumbuh kembang anak, yaitu terapi bermain. Peneliti menggunakan pop-up books sebagai media terapi. Pop-up books adalah sebuah buku yang memiliki bagian yang dapat bergerak atau memiliki unsur 3 dimensi serta memberikan visualisasi cerita yang lebih menarik, mulai dari tampilan gambar yang dapat bergerak ketika halamannya dibuka.

Menurut Handayani, et al., (2017) menunjukkan tingkat kecemasan dari 20 orang responden sebelum diberikan terapi bermain popup books sebagian besar yaitu 13 orang (65\%) dengan kategori cemas sedang, cemas berat 6 orang (30\%), kategori cemas berat sekali tidak ada dan kategori paling sedikit yaitu cemas ringan sebesar 1 orang $(5 \%)$.

Dampak kecemasan yang tidak segera ditangani akan membuat anak melakukan penolakan terhadap tindakan perawatan dan pengobatan yang diberikan sehingga berpengaruh terhadap lama rawatnya hari, memperberat kondisi anak dan bahkan dapat menyebabkan kematian pada anak. Kecemasan merupakan suatu perasaan yang berlebihan terhadap kondisi ketakutan, kegelisahan, kekhawatiran atau ketakutan terhadap ancaman nyata atau yang dirasakan (Saputro \& Fazrin, 2017).

Selanjutnya penelitian lain yang menggunakan popup-book sebagai terapi juga menemukan ada hubungan yang bermakna antara bermain pop-up books terhadap kecemasan, dimana pada hasil penelitian ditemukan ada penuruan skor kecemsan secara bermakna steralh terapi (Handayani, et al., 2017). Salah satu cara untuk mengalihkan perhatian anak dipengungsian/hunian sementara adalah dengan diberikannya dukungan sarana bermain yaitu 
terapi bermain pop-up books yang dapat memfasilitasi anak untuk mengurangi kecemasan dan ketakutan, karena anak usia sekolah masih senang bermain.

\section{METODE}

Penelitian ini menggunakan metode penelitian kuantitatif dengan quasi eksperimen one grup pre-test post-test. Populasi dalam penelitian ini adalah anak-anak prasekolah dan usia sekolah yang terdampak tsunami selat Sunda yang tinggal di hunian sementara desa Way Muli Timur, Way Muli Barat, dan Kunjir sebanyak 93 anak.

Penelitian dilakukan pada anak pra sekolah dan usia sekolah yang mengalami dampak bencana alam Tsunami Selat Sunda pada Desember 2018. Analisis masalah mental emosional menggunakan kuesioner kekuatan dan kesulitan pada anak.

Pengambilan sampel dilakukan dengan teknik purposive sampling. Teknik mengumpulan data menggunakan lembar observasi menggunakan alat ukur SDQ (Strenghts and Difficulties Questionnaire). SDQ adalah sebuah instrumen skrining perilaku singkat untuk anak dan remaja (3-17 tahun) yang memberikan gambaran singkat dari perilaku yang berfokus pada kekuatan dan juga kesulitan mereka (Black, Pulford, Christie, \& Wheeler, 2010). SDQ terdiri dari 25 item yang dialokasikan pada lima subskala. Keempat subskala termasuk ke dalam kelompok subskala kesulitan, yaitu subskala emotional symptom, subskala conduct problem, subskala hyperactivity-inattention, dan subs- kala peer problem. Sedangkan subskala yang kelima termasuk dalam kelompok subskala kekuatan, yaitu subskala pro-social. Masing-masing subskala SDQ terdiri dari lima item. Masingmasing item diskor dalam kriteria tiga poin yaitu $0=$ tidak benar, $1=$ agak benar, $2=$ sangat benar. Skor dari masing-masing subskala dapat dihitung dengan menjumlahkan skor dari masing-masing item yang relevan pada subskala tersebut. Skor tertinggi dari masing-masing subskala adalah 10 dan skor terendah adalah 0 (Goodman dalam Muris, Meesters, \& van den Berg, 2003). Intsrumen ini sudah dilakukan uji validasi (Oktaviana dan Wimbarti, 2014).

Terapi bermain pop-up books sebagai perlakuan diberikan secara berkala selama 3 minggu yang terbagi dalam 3 sesi pendampingan pada kelompok anak di tiap wilayah. Setiap responden dilakukan pengukuran mental emosional pada awal sebelum intervensi setiap kali sesi pendampingan dan pengukuran post dilakukan setelah pendampingan terakhir atau ketiga. Analisis yang digunakan adalah T-test dependent.

Penelitian ini telah mendapatkan persetujuan etik dari Komite Etik Penelitian Kesehatan Politeknik Kesehatan Tanjung Karang dengan Nomor 276/EA/KEPK-TJK/IX/2019.

\section{HASIL}

Tabel 1. Gambaran Karakteristik Responden Penelitian

\begin{tabular}{lrr}
\hline \multicolumn{1}{c}{ Variabel } & Jumlah & \% \\
\hline Usia & 5 & 5,4 \\
5 tahun & 24 & 25,8 \\
6 tahun & 21 & 22,6 \\
7 tahun & 12 & 12,9 \\
8 tahun & 23 & 24,7 \\
9 tahun & 8 & 8,6 \\
10 tahun & & \\
Jenis Kelamin & 49 & 52,7 \\
$\quad$ Perempuan & 44 & 47,3 \\
$\quad$ Laki-laki & & \\
Kehilangan Anggota Keluarga & 28 & 30,1 \\
$\quad$ Way Muli Timur & 42 & 45,2 \\
$\quad$ Way Muli Barat & 23 & 24,7 \\
$\quad$ Kunjir & & \\
Masalah Mental Emosional & 1 & 1,1 \\
$\quad$ Normal & 33 & 35,5 \\
$\quad$ Borderline & 59 & 63,4 \\
$\quad$ Abnormal
\end{tabular}

Tabel 2. Distribusi Responden Berdasarkan The Strengths and Difficulties Questionnaire

\begin{tabular}{lrr}
\hline $\begin{array}{c}\text { The Strengths and } \\
\text { Difficulties Questionnaire }\end{array}$ & Jumlah & $\%$ \\
\hline Emosional & & \\
$\quad$ Normal & 55 & 59,1 \\
Borderline & 18 & 19,4 \\
Abnormal & 20 & 21,5 \\
Conduct Problems & & \\
$\quad$ Normal & 24 & 25,8 \\
Borderline & 18 & 19,4 \\
Abnormal & 51 & 54,8 \\
Hyperactivity & & \\
Normal & 90 & 96,8 \\
Borderline & 3 & 3,2 \\
Abnormal & 0 & 0 \\
Peer Problem & & \\
Normal & 40 & 43 \\
Borderline & 33 & 35,5 \\
$\quad$ Abnormal & 20 & 21,5 \\
Prosocial & & \\
$\quad$ Normal & 57 & 61,3 \\
$\quad$ Borderline & 34 & 36,6 \\
$\quad$ Abnormal & 2 & 2,2 \\
\hline & &
\end{tabular}

Berdasarkan tabel 1, terlihat sebagian besar responden pada usia 6 tahun, yaitu 24 orang 
$(25,8 \%)$; berjenis kelamin perempuan yaitu sebanyak 49 orang $(52,7 \%)$; tinggal di Way Muli Barat sebanyak 42 orang $(45,2 \%)$; dan diketahui sebagian besar responden berada pada kategori abnormal, yaitu 59 orang $(63,4 \%)$

Hasil analisis pada tabel 2 diketahui sebagian besar gejala emosional responden berada pada kategori normal yaitu 55 orang $(59,1 \%)$, masalah perilaku responden berada pada kategoti abnormal yaitu 51 orang $(54,8 \%)$, hiperaktif-Inatensi responden berada pada kategoti normal yaitu 90 orang $(96,8 \%)$, hubungan dengan teman sebaya responden berada pada kategori normal yaitu 40 orang (43\%), dan masalah ketidakpedulian responden berada pada kategori normal yaitu 57 orang $(61,3 \%)$

Tabel 3. Skor Mental Emosional Sebelum Diberikan Terapi Bermain Pop-up Books

\begin{tabular}{ccccc}
\hline Mean & Median & SD & Min & Max \\
\hline 71,19 & 71,51 & 4,69 & 60 & 81 \\
\hline
\end{tabular}

Berdasarkan tabel 6 dapat diketahui bahwa rata-rata skor mental emosional anak kelompok responden sebelum mendapat terapi bermain sebelum mendapat terapi bermain pop-up books adalah 71,19 dengan standar deviasi 4,72 dan skor mental emosional anak terendah adalah 60 (cemas sedang) serta skor mental emosional tertinggi adalah 81 (cemas berat).

Tabel 4. Skor Mental Emosional Sesudah Diberikan Terapi Bermain Pop-up Books

\begin{tabular}{ccccc}
\hline Mean & Median & SD & Min & Max \\
\hline 41,20 & 41 & 7,53 & 32 & 58 \\
\hline \multicolumn{3}{c}{ Berdasarkan tabel } & 4 dapat diketahui bahwa
\end{tabular}
rata-rata skor mental emosional kelompok responden sesudah mendapat terapi bermain popup books adalah 41,20 dengan standar deviasi 7,53 dan skor mental emosional terendah adalah 32 (cemas ringan) serta skor kecemasan tertinggi adalah 58 (cemas sedang).

Tabel 5. Skor Mental Emosional Sebelum dan Sesudah Diberikan Terapi Bermain Pop-up books

\begin{tabular}{lrrrrr}
\hline $\begin{array}{c}\text { Mental } \\
\text { emosional }\end{array}$ & Mean & Med & SD & $\begin{array}{c}\text { Min- } \\
\text { Max }\end{array}$ & $\begin{array}{c}\boldsymbol{p} \text { value } \\
\text { value }\end{array}$ \\
\hline Sebelum & 71,19 & 71,51 & 4,69 & $60-81$ & 0,002 \\
Sesudah & 41,20 & 41 & 7,53 & $32-58$ & \\
\hline
\end{tabular}

Berdasarkan tabel 5 dapat diketahui bahwa rata-rata skor mental emosional setelah perlakuan menurun dibandingkan sebelum perlakuan dengan selisih skor sebesar 30 poin, dengan nilai $p$-value $<0,05$. Hasil ini menunjukkan ada perbedaan yang bermakna masalah mental emosional anak sebelum dan sesudah terapi bermain pop-up books. Hasil ini menunjukkan ada pengaruh terapi bermain pop-up books terhadap masalah mental emosional anak.

Analisis dilakukan berdasarkan perhitungan sebaran skor jawaban untuk pernyataan positif tidak benar $=0$, agak benar $=1$, dan benar $=2$. Skor untuk pernyataan negatif tidak benar $=2$, agak benar $=1$, dan benar $=0$. Hasil analisis pada variabel masalah mental emosional anak secara keseluruhan menunjukkan kondisi abnormal. Namun saat dilakukan analisis satu persatu pada subvariabel diperoleh kondisi yang berbeda. Secara keseluruhan masalah mental emosional anak tinggi pada ketidakpedulian (skor $3,2)$, gejala emosional $(2,1)$, hiperaktif $(1,76)$, masalah relasi dengan teman sebaya $(1,4)$, dan masalah perilaku $(1,3)$.

\section{PEMBAHASAN}

Hasil analisis pada subvariabel untuk masalah/gejala emosional masalah lebih tinggi pada pertanyaan nomor $16(\mathrm{E} 4)$, yaitu gugup/sulit berpisah dengan orang tua/pengasuhnya pada situasi baru, mudah kehilangan rasa percaya diri. Skor terendah pada pertanyaan nomor 3 (E1), 8 (E2), 13 (E3), dan 24 (E5).

Hasil analisis pada subvariabel untuk masalah tingkah laku, masalah lebih tinggi pada pertanyaan nomor $7(\mathrm{C} 2)$, yaitu umumnya anak bertingkahlaku baik, biasanya melakukan apa yang disuruh oleh orang dewasa. Skor terendah pada pertanyaan nomor 22 (C5), yaitu mencuri dari rumah, sekolah atau tempat lain.

Hasil analisis pada subvariabel untuk masalah hiperaktifitas, masalah lebih tinggi pada pertanyaan nomor 21 (H4), yaitu sebelum melakukan sesuatu ia berpikir akan akibatnya dan pertanyaan nomor 25 (H5), yaitu memiliki perhatian yang baik terhadap apapun, mampu menyelesaikan masalah, tugas atau pekerjaan rumah sampai selesai. Skor terendah pada pertanyaan $(\mathrm{H} 2)$, yaitu terus menerus bergerak dengan resah/menggeliat-geliat.

Hasil analisis pada subvariabel untuk masalah teman sebaya, masalah lebih tinggi pada pertanyaan nomorr 11 (P2), yaitu mempunyai satu atau lebih teman dan pertanyaan 14 (P3) yaitu pada umumnya disukai oleh anak-anak lain. Skor terendah pada pertanyaan nomor 6 (P1) yaitu cenderung menyendiri; 19 (P4) pada umumnya disukai anak-anak lain; dan 23 (P5) 
lebih mudah berteman dengan orang dewasa dibanding anak-anak lain.

Hasil analisis pada subvariabel untuk masalah prosocial/ketidakpedulian, masalah lebih tinggi pada pertanyaan nomor $17(\operatorname{Pr} 4)$, yaitu bersikap baik pada anak-anak yang lebih muda. Skor terendah pada pertanyaan nomor 4 (Pr2), yaitu kalau mempunyai mainan, kesenangan, atau pensil, anak bersedia berbagi dengan anak-anak lain.

Anak-anak adalah kelompok yang rentan. Temuan penelitian memberikan kesan bahwa anak usia prasekolah menunjukkan distres psikologis dan masalah kognitif yang rendah jika dibandingkan pada anak yang lebih tua. Bagimanapun juga mereka cenderung untuk memperlihatkan insiden yang tinggi terhadap ketakutan umum dan spesifik, kehilangan kemampuan bahasa, masalah perilaku (tempertantrum, agresif), ketergantungan, kecemasan akibat perpisahan, iritabel, mimpi buruk, dan perilaku regresi spesifik (seperti memasukan ibu jari ke mulut, dan ngompol). Gempa bumi secara konsisten terbukti berhubungan dengan masalah kesehatan mental seperti depresi dan gangguan stres paska-trauma, sebuah survey menunjukkan bahwa, setelah peristiwa bencana, sekitar $15-20 \%$ populasi akan mengalami gangguan mental ringan atau sedang yang merujuk pada kondisi post-traumatic stress disorder (PTSD), sementara 3-4\% akan mengalami gangguan berat seperti psikosis, depresi berat dan kecemasan yang tinggi (Sherchan, et al., 2017).

Penelitian lain mengindikasikan adanya tingkat yang tinggi dari trauma spesifik dan ketakutan umum diantara anak usia prasekolah mengikuti kejadian traumatik. Permasalahan yang ditemukan pada anak korban gempa adalah yang pertama berubah sikap seperti anak menjadi lebih sensitif, mudah menangis, mudah marah, ketika mendengar ada yang bergemuruh langsung panik dan menangis, sering khawatir masuk rumah, siapa awalnya ceria dan cemas. cerdas setelah gempa lebih diam dan menarik diri. Gejala kecemasan klinis yang dialami anak dapat menimbulkan gejala PTSD (Thoyibah, et al., 2019).

Anak usia prasekolah yang terpapar badai tornado Illinois menunjukkan $88 \%$ takut terhadap angin ribut, $67 \%$ takut sendirian dan 56\% takut kegelapan dan kecelakaan. Gejala PTSD lebih umum dilaporkan oleh anak usia sekolah (Purnamasari, 2016).

Penelitian lain terhadap tingkat PTSD yang dilakukan pada anak usia sekolah secara umum menunjukkan setiap kali ada bencana selalu diikuti oleh kejadian PTSD pada anak. Minimal PTSD yang terjadi sebagai ikutan dari bencana terjadi pada tingkat menengah sampai dengan ketingkat yang berat. PTSD selalu terjadi pada anak setiap kali kejadian bencana (Rahmadian, et al., 2016). Selanjutnya juga dilaporkan kondisi masalah psikologis dan gangguan tidur pada anak pasca bencana (Itagaki, et al., 2018).

Secara keseluruhan, anak sekolah yang selamat dari bencana memperlihatkan ketakutan pada tingkat yang tinggi, gejala somatik yang luas, masalah kognitif, perilakku dan masalah sosial. Masalah kognitif meliputi kurang konsentrasi, permasalahan membaca dan pemahaman dan menurunnya performance di sekolah. Masalah terkait perilaku diantaranya seperti perilaku menolak dating kesekolah dan ketidakmampuan konsentrasi. Perilaku anak menjadi tidak konsisten seperti mudah marah, tidak sopan dan secara emosional menjadi sensitif. Oleh karena itu, teman sebayanya mungkin menjadi menderita karena perilakuini. Mereka juga mungkin mengalami kehilangan support social seperti teman. Penelitian juga mengindikasikan bahwa perbandingan anak usia prasekolah dengan anak usia sekolah terhadap tingkat gejala PTSD dan mempunyai pemahaman yang lebih tinggi pada anak usia sekolah terhadap pengalaman yang traumatic.

Kondisi mental emosional anak seteleh terapi menunjukan peningkatan yang signifikan. Hasil uji menunjukkan ada pengaruh terapi bermain dengan pop-up book terhadap masalah mental emosional anak. Beberapa penelitian terdahulu menunjukkan pengalaman traumatis pada anak akan berkurang melalui terapi bermain.

Trauma anak bisa ditangani melalui empat teknik, yaitu teknik relaksasi, teknik mengekspresikan emosi, teknik rekreasional, teknik ekspresif. Upaya penerapan terapi rekreasion ini memberikan keringanan beban pikiran yang dirasakan pada penyintas,

Mengurangi rasa ketegangan, mengurangi rasa takut, menghapus memori yang membuat trauma terkait dengan bencana, memudarkan ingatan anak tentang bencana yang pernah dirasa, dan membuat suasana hari menjadi lebih rileks, serta semakin baik memulihkan kondisi mental anak. Pada akhirnya, kehidupan anak dapat kembali normal dalam beberapa hari atau minggu setelah peristiwa yang mengerikan tersebut (Safitri, et al., 2021). Selanjutnya penelitian lain menunjukkan bahwa pop-up books identik dengan anak-anak dan mainan, merupakan media ini berisi cerita bergambar yang memiliki bentuk tiga dimensi ketika 
halaman buku dibuka. Terapi bermain merupakan salah satu teknik yang akan membantu penurunan ketegangan emosional yang dirasakan anak. Secara bertahap respon psikis maupun fisiologis kecemasan akan berkurang (Handayani, et al., 2017). Bagi anak-anak yang mengalami PTSD teknik yang sesuai untuk mengatasi kondisi trauma adalah dengan menggunakan teknik play therapy (Nawangsih, 2016). Upaya yang bisa dilakukan untuk menyembuhkan trauma pada dasarnya adalah kegiatan mengajak korban untuk dapat merasa lebih tenang dan damai sehingga dapat memiliki pandangan baru (Darmiany, 2019; Pratiwi, 2017; Salamor, et al., 2020)

Beberapa penelitan lain menunjukkan ada pengaruh yang signifikan antara terapi bermain dengan kondisi trauma pasca bencana. Anak menjadi lebih tenang dan nyaman melalalui terapi bermain, dapat mengekspresikan perasaannya melalui tahapan permainan. Tanpa disadari bermain menjadi arena untuk mengekspresikan perasaan kesedihan dan stress anak (Pramardika, Hinonaung, et al., 2020; Pramardika, Siska, et al., 2020 ; Haryati, 2019).

Berdasarkan hasil penelitan ini dan penelitian terdahulu jelas bahwa terapi bermain merupakan metode yang efektif untuk mengatasi kondisi pikologis atau masalah mental dan emosi pada anak.

\section{DAFTAR PUSTAKA}

Ali Rahmadian, A., . F., Yusuf L.N, S., Rusmana, N., \& L. Downs, L. (2016). Prevalensi Ptsd Dan Karakteristik Gejala Stres Pascatrauma Pada Anak Dan Remaja Korban Bencana Alam. Edusentris, 3(1), 1. https://doi.org/10.17509/edusentris.v3i1.184

Darmiany. (2019). Pgsd Untuk Negeri: Terapi Bermain Sebagai Bentuk Trauma Healing Bagi Anak-Anak Korban Gempa Lombok. Jurnal Pendidikan Dan Pengabdian Masyarakat, 2(2).

Handayani, N., Badi'ah, A., \& Ermawan, B. (2017). Pengaruh Terapi Bermain Pop- Up Book Terhadap Kecemasan Preoperatif Menggunakan Anestesi Umum Pada Anak Usia Sekolah Di Rs Pku Muhammadiyah Yogyakarta. Caring : Jurnal Keperawatan, 6(2), 94-105.

https://doi.org/10.29238/caring.v6i2.351.

Haryati, S. (2019). Terapi Bermain "Trauma Healing” Dengan Alat Permainan Edukatif (APE) Buatan Sendiri Pasca Gempa Pada Peserta Didik Kelompok TK A Paud Terpadu Putra Kaili Permata

\section{SIMPULAN}

Hasil analisis pada variabel masalah mental emosional anak secara keseluruhan menunjukkan kondisi abnormal. Namun saat dilakukan analisis satu persatu pada subvariabel diperoleh kondisi yang berbeda. Secara keseluruhan masalah mental emosional anak tinggi pada ketidak pedulian (skor 3,2), gejala emosional $(2,1)$, hiperaktif $(1,76)$, masalah relasi denga teman sebaya $(1,4)$, dan masalah perilaku $(1,3)$. Ada perbedaan yang signifikan kondisi mental emosional anak sebelum dan sesudah perlakuan dengan pop-up book.

Perlu dikembangkan psikoterapi dalam asuhan keperawatan keluarga dengan penyintas usia anak-anak, khususnya yang terdampak bencana alam yang sering terjadi saat ini, dengan melakukan kerja sama dengan intitusi pendidikan dan organisasi seperti ikatan perawat kesehatan jiwa (IPKJI) untuk penerapan keperawatan kesehatan jiwa komunitas, salah satunya dengan terapi bermain. Perlu dikembangkan terapi bermain lain yang sesuai dengan kearifan lokal, seperti bercerita dengan tradisi Lampung/mendongeng yang lebih dikenal dengan pisaan.

Bangsa. Sulawesi Tengah: Best Practice. Perlombaan Penulisan.

Itagaki, S., Ohira, T., Nagai, M., Yasumura, S., Maeda, M., Suzuki, Y., Mashiko, H., Shiga, T., Miura, I., \& Yabe, H. (2018). The relationship between sleep time and mental health problems according to the strengths and difficulties questionnaire in children after an earthquake disaster: The Fukushima health management survey. International Journal of Environmental Research and Public Health, 15(4). https://doi.org/10.3390/ijerph15040633.

Nawangsih, E. (2016). Play Therapy Untuk anakanak Korban Bencana Alam Yang Mengalami Trauma (Post Traumatic Stress Disorder/PTSD). Psympathic: Jurnal Ilmiah Psikologi, 1(2), 164-178. https://doi.org/10.15575/psy.v1i2.475.

Oktaviana, M., \& Wimbarti, S. (2014). Validasi Klinik Strenghts and Difficulties Questionnaire (SDQ) sebagai Instrumen Skrining Gangguan Tingkah Laku. Jurnal Psikologi, $\quad 41(1), \quad 101$. 
https://doi.org/10.22146/jpsi.6961.

Pramardika, D. D., Hinonaung, J. S. H., \& Mahihody, A. J. (2020). Pengaruh Terapi Bermain Terhadap. 7(2), 85-91.

Pramardika, D. D., Siska, J., Hinonaung, H., Mahihody, A. J., \& Wuaten, G. A. (2020). Terapi Bermain Sebagai Trauma Healing Pada Anak. 3, 167-172.

Pratiwi, S. A. (2017). Play therapy untuk post traumatic stress disorder pada anak korban bencana. Journal of Chemical Information and Modeling, 31-38.

Purnamasari, I. (2016). Perbedaan reaksi anak dan remaja pasca bencana. Jurnal Penelitian dan Pengabdian Kepada Masyarakat UNSIQ, 3(1), 49-55.

Radityo S, A. N., Utami, D., \& Hartanto, F. (2012). Masalah Mental Dan Emosional Pada Siswa SMP Kelas Akselerasi Dan Reguler (Studi Kasus Di SMP Negeri 2 Semarang). Jurnal Kedokteran Diponegoro, 1(1), 107008.

Rahmadian, A. A., Rusmana, N., \& Downs, L. L. (2016). Prevalensi PTSD dan Karakteristik Gejala Stres Pascatrauma Pada Anak dan Remaja Korban Bencana Alam. Edusentris, 3(1), 1-17.

Safitri, R. P., Jumadi, J., Romadonika, F., \& Adithia, E. (2021). Mencegah Trauma Pasca Bencana Gempa Bumi pada Anak dengan Terapi Rekreasional di Lombok Utara. ADMA: Jurnal Pengabdian dan Pemberdayaan Masyarakat, 2(1), 95-100. https://doi.org/10.30812/adma.v2i1.1265

Salamor, A. M., Salamor, Y. B., \& Ubwarin, E. (2020). Trauma Healing Dan Edukasi Perlindungan Anak Pasca Gempa Bagi Anak-Anak Di Desa Waai. Communnity Development Journal, 1(3), 320.

Saputro, H., \& Fazrin, I. (2017). Anak Sakit Wajib bermain di Rumah Sakit: penerapan terapi bermain anak sakit; proses, pelaksanaan \& manfaatnya. Forum Ilmiah Kesehatan https://doi.org/978-6021081-44-0.

Sherchan, S., Samuel, R., Marahatta, K., Anwar, N., Van Ommeren, M. H., \& Ofrin, R. (2017). Post-disaster mental health and psychosocial support: Experience from the 2015 Nepal earthquake. WHO South-East Asia Journal of Public Health, 6(1), 22-29. https://doi.org/10.4103/2224-3151.206160.

Thoyibah, Z., Dwidiyanti, M., Mulianingsih, M., Nurmayani, W., \& Wiguna, R. I. (2019). Gambaran Dampak Kecemasan dan Gejala Psikologis pada Anak Korban Bencana Gempa Bumi di Lombok. Holistic Nursing and Health Science, 2(1), 31-38. https://doi.org/10.14710/hnhs.2.1.2019.31-38. 